\title{
Title Index of Volume 2
}

\section{EDITORIALS}

\section{LETTERS TO THE EDITOR}

$1,49,113,153$

$1,49,113,153$

\section{UNITED NATIONS ACTIVITIES}

The UN Environment programme: Four years after Stockholm (D. S. Zalob)

The New York Session of the 3rd UN Law of the Sea Conference: Progress or stagnation?

(A. R. H. Schneider)

Habitat: Shaping the global village (R. D. Munro)

Key issues at the Fifth Session of the UN Law of the Sea Conference (D. H. Anderson)

Environmental law activities at UNEP

Environmental developments at the General Assembly (D. S. Zalob)

\section{OTHER INTERNATIONAL DEVELOPMENTS}

Civil liability for pollution from offshore operations: Chairman's notes (Peter Archer)

Norwegian view (Carl A. Fleischer)

Technological assessment

Alternative approaches to transfrontier environmental injuries (Ignaz Seidel-Hohenveldern)

Fish and the sea - The ICNAF meeting at Montréal (Frank G. Müller)

Royal flush

Environmental policy institute meets

Environmental protection in member countries of the CMEA: A survey (Antonín Sum)

Legal principles applicable to the conservation of migratory species (Cyrille de Klemm)

Pollution control in the Mediterranean

The Fourth International Parliamentary Conference on the Environment: A summary report (S. Vitzthum)

NATO and the environment: A challenge for a challenger (M. Sudarskis)

ICAO's action against aircraft noise pollution (part 1) (R. Goy)

Equal right of access: transfrontier pollution (S. Van Hoogstraten, P. Dupuy et H. Smets)

Conferring of the Elizabeth Haub prize

Transfrontier cooperation in the Upper Rhine area (A. Ch. Kiss et M. Prieur)

Update

Report on the Rhine situation

Draft International Convention on the Conservation of Migratory Species of Wild Fauna (D. B. Navid)

The Darién Gap Highway: Manifest destiny revisited (E. V. Coan and M. Moss)

ICAO's action against aircraft noise pollution (part 2) (R. Goy)

Environmental Program of the European Communities Interview with Maurice F. Strong Update
Criminal law and environmental protection

(M. Delmas-Marty)

161

The Washington Convention: First meeting of the conference of the Parties (D. B. Navid)

Darién Gap injunction extended

European Parliament: Proposal for a directive from the Commission on bird protection

The signing of two conventions for the protection of the Rhine

Council of Europe \& wildlife conservation

\section{NATIONAL AFFAIRS}

Papua New Guinea opts for eco-development (Jimoh Omo-Fadaka)

The California coastal plan -.. A summary report (David S. Zalob)

China's environomics: Backing into ecological leadership (part II) (Leo A. Orleans)

UNEP working group discusses shared resources

Miniscule budget for the environment in France

The role of the US congress in international environmental conservation (Harvey R. Sherman)

5 Quarrying in Israel - Administrative roulette (Richard Laster)

Legal protection of the natural environment in a socialist state ... The Polish system (Wacław Brzezinski)

9 Toxic substances legislation - Regulators $v$ s. science

10 (part 1) (E. H. Blair and F. D. Hoerger)

(part 1) (E. H. Blair and F. D.

I. Environmental protection in the UK (E. T. Lummis) 87

II. Representative view for the others (G. Hartkopf) 89

Taxation as an instrument of pollution control (part 1) (M. J. Forster)

Environmental law and administration in Israel (E. Katin) 94

China's environomics: Backing into ecological leadership (part III) (L. A. Orleans)

First Congress of the French Association for Environmental Law (A. Ch. Kiss)

France: Bold environment bill passed

72 Polar bear protection

Should we recognize nature's claim to legal rights? An essay (G. Stutzin)

The US Federal Noise Control Act (J. S. Winder Jr.)

Taxation as an instrument of pollution control (part II) (M. J. Forster)

83 The Naturschutzwacht: A unique environment corps (M. Streibl)

The Nonsense of Non-degradable wrappers

oxic substances legislation - Regulators vs. science (part II) (E. H. Blair and F. D. Hoerger)

Seveso and the Common Market

Ministerial-level session of the International Commission for the Protection of the Rhine against pollution 
Nature : The public access issue

We may be brothers after all

Pollution costs, political jurisdictions and economic markets (M. C. McGuire and N. M. Singer)

Reclamation and rollcalls: The political struggle over stripmining (P. T. Mink)

US referenda: Setback for environmentalists

\section{SELECTED DOCUMENTS}

Convention for the protection of the Mediterranean sea against pollution

OECD Council Recommendation on equal right of access in relation to transfrontier pollution

European Council of Environmental Law - Resolution passed on October 18th 1975

Decisions of the Governing Council of the United Nations Environment Programme at its Fourth Session

Resolutions of the Fourth International Parliamentary Conference on the Environment

Habitat

IUCN Statement for Third UN Conference on the Law of the Sea

Convention concerning the protection of the Rhine against pollution by chlorides

Convention concerning the protection of the Rhine against chemical pollution $\quad 185$

$\begin{array}{ll}\text { Supplementary Agreement } & 187\end{array}$

$\begin{array}{ll}\text { Senate Resolution } 521 & 188\end{array}$

First Meeting of the Conference of the Parties, Bern

(Switzerland), 2 to 6 November 1976

\section{BOOK NOTES}

The law of the sea - Current problems 48

The spheres of life - An introduction to world ecology 48

Tropical marine pollution $\quad 48$

45 Human settlements - Crisis and opportunity 48

International Protection of the Environment. Treaties $\begin{array}{ll}\text { and Related Documents } & 112\end{array}$

An individual right or an obligation of the State 112

105 Private property and the public interest: the Brandywine experience

105 Human rights and environment: The need for international co-operation

109 Economics of transfrontier pollution

150 A national policy for the environment - NEPA and its aftermath

\section{Author Index of Volume 2}

Anderson, D. H., 154

Archer, Peter, 2

Blair, E. H., 84, 138

Brzezinski, Wacław, 41

Coan, Eugene V., 120

De Klemm, Cyrille, 16

Delmas-Marty, Mireille, 161

Dupuy, Pierre, 77

Fleischer, Carl August, 3

Forster, Malcolm J., 92, 133

Goy, Raymond, 72, 122

Hartkopf, G., 89

Hoerger, F. D., 84, 138
Jorling, Thomas C., 140

Katin, Ernest, 94

Kiss, A. Ch., 81, 102

Lummis, Eric T., 87

McGuire, Martin C., 172

Mink, Patsy T., 176

Moss, Michael, 120

Müller, Frank G., 9

Munro, Robert D., 114

Navid, Daniel B., 116, 167

Omo-Fadaka, Jimoh, 20

Orleans, Leo A., 28, 98

Prieur, M., 81
Schneider, A. R. H., 60

Seidl-Hohenveldern, Ignaz, 6

Sherman, Harvey R., 32

Singer, Neil M., 172

Smets, Henri, 77

Streibl, Max, 137

Stutzin, Godofredo, 129

Sudarskis, Michel, 69

Sum, Antonín, 11

Van Hoogstraten, Steven, 77

Vitzthum, Stella, 66

Winder, John S., Jr., 130

Zalob, David S., 23, 50, 159 